\title{
Reconciliation and psychiatry in South Africa
}

\author{
Bernard Janse van Rensburg
}

Associate Professor Department of Psychiatry, University of the Witwatersrand, Johannesburg. Wourg South Afri South African Society of Psychiatrists, email bernard.jvr@ gmail.com

\begin{abstract}
Although psychiatrists did not form part of the structures of the South African Truth and Reconciliation Commission (TRC), the Society of Psychiatrists of South Africa (SPSA) at the time did make a submission. Since then, the local association of psychiatrists has been reconstituted as the South African Society of Psychiatrists (SASOP). Psychiatry and psychiatrists may have to extend their activities beyond rehabilitation and restoration, to include endeavours to prevent future violations of human rights.
\end{abstract}

\section{Truth and reconciliation in South Africa}

The South African Truth and Reconciliation Commission (TRC) undertook its work from 1996 to 1998 with the mandate to recommend measures 'to prevent future violations of human rights' and in relation 'to rehabilitating and restoring the human and civil dignity of victims'. The chair, Archbishop Emeritus Desmond Tutu, submitted his report in October 1998:

It is not and cannot be the whole story; but it provides a perspective on the truth about a past that is more extensive and more complex than any one commission, in two and a half years, could hope to capture. (TRC, 1998: vol. 1, ch. 1, p. 1)

Local authors reported extensively at the time on the experiences and meaning of the process (Krog, 1998), followed by others (Du Bois \& Du Bois-Pedain, 2009). The addendum to this paper outlines some of the further work done since.

In April 2006, a follow-up congress, 'The TRC: Ten Years On', was organised by the Institute for Justice and Reconciliation, funded by Danish and Flemish donors. It reviewed the TRC's unfinished business at the time (Villa-Vicencio \& Du Toit, 2006). Four areas of unfinished business received attention: (1) government decisions regarding the prosecution of those who either were denied amnesty or refused to apply for it; (2) reparations for those found by the TRC to be victims of gross violations of human rights; (3) access to the TRC archives; and (4) national reconciliation.

In terms of the prosecution and reparation that affected the South African medical fraternity in particular, it is surely the death of Steve Biko $^{1}$ and

1. Steve Biko, a medical doctor, anti-apartheid activist and founder of the Black Consciousness Movement, was arrested and interrogated in Port Elizabeth in August the position of the Medical Association of South Africa (MASA) during apartheid that should be recalled (Rubenstein \& London, 2001), as well as the case of the physician Wouter Basson, former head of the apartheid chemical and biological weapons programme ('Project Coast'). While Basson was acquitted in 2002 of criminal charges, and appeals to this ruling were dismissed by the Supreme Court of Appeal and the Constitutional Court in 2005, the Health Professions Council of South Africa (HPCSA) in December 2013 found him guilty of unethical conduct (Mail \& Guardian, 2013). His sentencing procedure started in November 2014, but was postponed to 2015 .

In terms of the unfinished business of national reconciliation, it can be noted that the death of Nelson Mandela in December 2013 afforded an opportunity for informal review and contemplation of our progress as a nation on this road 20 years later, with a fairly general realisation that reconciliation, transformation and integration have not been completed, or, in some instances, not even been undertaken yet.

\section{Psychiatry's previous participation}

While no psychiatrists were included in the different activities of the TRC, the then Society of Psychiatrists of South Africa (SPSA) did submit a formal report (available from the author on request; see also TRC, 1998: vol. 4, ch. 5, p. 142). The report provided an overview of the history of the SPSA since its formation in the early 1950 s and alluded to visits and/or reports by the World Health Organization (WHO, 1977, 1981), American Psychiatric Association (APA, 1979), American Association for the Advancement of Science (AAAS, 1990), Royal College of Psychiatrists (RCPsych, 1983), as well as to the SPSA's reply to the World Psychiatric Association (WPA) in response to calls for its expulsion (Jablensky, 1978). The SPSA subsequently established a Human Rights Subcommittee in 1986, while its TRC submission pointed to several statements, resolutions and press releases issued from 1986 to 1989 and in 1995.

Emsley (2001) reported on the state of psychiatry and mental healthcare in South Africa at the time, and Stein et al (2008) published findings on the relation between psychiatric status and forgiveness

1977 by South African Security Police, which included torture and beatings resulting in a coma. On 11 September he was transported in the back of a vehicle on a $1100 \mathrm{~km}$ journey to Pretoria, where he died in prison on 12 September 1977. 
among survivors of human rights abuses, and on the impact of the TRC on psychological distress and forgiveness (Kaminer et al, 2001). Stein's group was also responsible for the first, and to date only, large-scale population-based study of common mental health disorders in the country, the South African Stress and Health (SASH) study (Heeringa et al, 2009), which was recently quoted by a local media report that highlighted the ongoing generally poor state of mental healthcare in South Africa (Sunday Times, 2014). The SASH study formed part of the WHO's World Mental Health initiative and was placed within the historical context of early post-apartheid South Africa, where communities were sharply divided (and indeed still are).

\section{Truth and reconciliation elsewhere}

As described in the thematic paper by Jason Lee in this issue, a recent encouraging example of a body of psychiatrists involving themselves actively with a local process of reconciliation is the innovative initiative of the Royal Australian and New Zealand College of Psychiatrists on reconciliation with the Aboriginal and Torres Strait Islander people (RANZCP, 2011, 2014). Its 2014-16 Action Plan, with measurable outcomes, includes: building relationships; respect and value for culture and history; and providing opportunities for trainees and members to engage and build cultural competency skills. It must also be noted that the WPA Action Plan for 2014-17 includes refugees and asylum seekers in prioritised action to promote the mental health of the most vulnerable of population groups (Bhugra, 2014).

\section{Psychiatry's required participation}

It can be noted that the local association of psychiatrists has, since the conclusion of the TRC's activities, been reconstituted in its entirety. Since 2008 it has existed as the South African Society of Psychiatrists (SASOP), with a current memorandum of incorporation as a non-profit, membership-driven, private company and, as such, is not cast in any way as a statutory body of the state. The SASOP has adopted objectives such as to promote and uphold the principles of human rights, dignity and ethics in the practice of psychiatry, and to oppose unfair discrimination in the field of psychiatry. It has around 600 members, of a total of about 700 psychiatrists serving a population of some 50 million. There are currently also several South African psychiatrists in other countries, such as the UK, Australia and Canada.

Considering the above and the original mandate of the TRC it seems important that current involvement in reconciliation should go beyond dealing only with the consequences of conflicts after many years and much destruction (rehabilitation and restoring), to actively seeking 'to prevent future violations of human rights'. This may require a significant shift in psychiatry's current thinking, to move beyond its traditional scope of biological practice and intervening only in terms of neurochemical and subsequent clinical results of stress- and trauma-related anxiety, mood or substance disorders. Psychiatry may have to consider pre-emptive social interventions and involvement in social issues and political conflicts, in order to avert the devastating results of already escalated conflicts. Should psychiatry and psychiatrists involve themselves in military conflict management and resolution, as in Ukraine, Syria, Iraq and Afghanistan? Should they involve themselves in the pervasive reality of international human trafficking (United Nations, 2014)? Or in resisting abusive legislation regarding homosexuality in Uganda (Ugandan Government, 2009)?

Many national associations like the SASOP, however, are, constitutionally, small, voluntary, non-profit, private enterprises that, at best, have achieved some strategic space to offer comments and statements as non-governmental organisations. Although the SASOP has created divisions and task teams to engage in the protection of human rights and prevention of stigma and discrimination, its challenge will remain to position itself more strategically and to adopt a broader social role than it has so far occupied, despite the discourse becoming progressively less psychiatric and more social-political (Robertson \& Walter, 2011).

\section{Conclusion}

The South African experience (the SPSA during the 1970 s and 1980s) seems to suggest that the review of national psychiatric associations in countries where conflicts with potential human rights abuses may occur should probably be ongoing. Such scrutiny may be the role of the WPA and of collective bodies of associations, such as the European Psychiatric Association (EPA), the Asian Federation of Psychiatric Associations (AFPA) or a future African association of psychiatric associations. The aim should be not only to strengthen and assist national associations to formulate position statements, strategies and actions, but also to engage them on their own positions and actions regarding such challenging local scenarios.

In this regard it can be noted that the SASOP will be co-hosting a WPA International Congress in Cape Town in November 2016, which should be an opportunity to address what aspects of reconciliation, transformation and integration of our communities and of our clinical practice have not been completed or, in some instances, not even undertaken yet. The theme of the Congress will be 'Psychiatry: Integrative Care for the Community' and it will explore concepts, controversies and consequences of psychiatry's responsibility and accountability to society in terms of its scope of practice and of what can be considered psychiatry's social contract. ${ }^{2}$

2. 'Transformation also includes reconciliation and creating a nation united in the rich diversity of communities previously forced apart.' Nelson Mandela, State of the Nation Address, South African Parliament, 10 February 1999. 


\section{Addendum}

\section{Memory and reconciliation}

One response to enduring trauma, stress and loss incurred from conflicts and human rights abuses is its processing through ceremony, rituals and commemoration. The Freedom Park in Pretoria was established in 2002 as an expression and direct continuation of the processes of the TRC (http://www.freedompark.co.za). The site now includes a sacred ceremonial space in a garden of remembrance, a museum and exhibition space, and a Wall of Names of victims of the main eight South African conflicts over past centuries - the pre-colonial wars, slavery, genocide, wars of resistance, the South African (Anglo-Boer) War and the First and Second World Wars and the liberation struggle. Following the notion of Chidester (2006), the site has been promoted to use African cleansing and healing ceremonies described by the Freedom Park Trust as 'strategic interventions in the quest for symbolic reparation of the nation'. The site is also required and expected to restore indigenous African forms of spirituality - the Freedom Park Trust says 'to follow [the nation's] liberation also from colonial spirituality', which was mainly religious and Christian in nature (Freedom Park Trust, undated).

Another public institution that can be cited in this regard is the inclusion of 16 December in the South African public holiday calendar as national Reconciliation Day.

\section{Reconciliation components}

Literature and TRC documentation allude to several components of reconciliation, such as: truth telling; forgiveness; remorse; restitution; justice; memory and remembrance; as well as restorative action and transcendence through spiritual/religious or other means. These components eventually form part of history and even subsequent myth making, while all these have to find crucial expression in different art forms, whether in writing, visual arts, dance or music. Allais (2008a) considered the role and meaning of forgiveness in a philosophical sense. She also developed an account of forgiveness which allows that the TRC did not require forgiveness for its process to work, but that victims who offered forgiveness for atrocities were not making a moral mistake, even if they did this in the absence of repentance of the wrongdoer (Allais, 2008b). These philosophical contributions demonstrate how academic disciplines, including psychiatry, can and should include components of reconciliation in their scope of attention and practice.

\section{References}

AAAS (1990) Apartheid Medicine: Health and Human Rights in South Africa. Medical Mission to South Africa, American Association for the Advancement of Science.

Allais, L. (2008a) Wiping the slate clean: the heart of forgiveness. Philosophy and Public Affairs, 36, 33-68.

Allais, L. (2008b) Forgiveness and mercy. South African Journal of Philosophy, 27, 1-9.
APA (1979) Report on the Special Committee of APA visit to South Africa. American Journal of Psychiatry, 136, 1498-1506.

Bhugra, D. (2014) The WPA Action Plan 2014-2017. World Psychiatry, 13, 328.

Chidester, D. (2006) Indigenous traditions, alien abductions: creolized and globalised memory in South Africa. In Religion, Violence, Memory and Place (eds O. B. Stier \& J. S. Landres), pp. 181-197. Indiana University Press.

Du Bois, F. \& Du Bois-Pedain, A. (eds) (2009) Justice and Reconciliation in Post-Apartheid South Africa. Cambridge University Press.

Emsley, R. A. (2001) Focus on psychiatry in South Africa. British Journal of Psychiatry, 178, 382-386.

Freedom Park Trust (undated) Spirituality and the Secular State: $A$ Preliminary Perspective. Freedom Park Trust:

Heeringa, A., Stein, D. J., Seedat, S., et al (2009) The South African Stress and Health (SASH) study: 12-month and life-time prevalence of environmental disorders. South African Medical Journal, 99, 339-344.

Jablensky, A. (1978) Mental health care in South Africa. Lancet, 8058, 270-271.

Kaminer, D., Stein, D. J., Mbanga, I., et al (2001) The Truth and Reconciliation Commission in South Africa: relation to psychiatric status and forgiveness among survivors of human rights abuses. British Journal of Psychiatry, 178, 373-377.

Krog, A. (1998) Country of My Skull: Guilt, Sorrow and the Limits of Forgiveness in the New South Africa. Broadway Books.

Mail \& Guardian (2013) Basson guilty of professional misconduct. Mail \& Guardian, 18 December. Available at http://mg.co.za/ article/2013-12-18-basson-guilty-of-professional-misconduct (accessed 23 December 2014).

RANZCP (2011) Recognition of Indigenous people in the Australian Constitution (Position Statement 68). Royal Australian and New Zealand College of Psychiatrists. Available at https://www.ranzcp. org/Files/Resources/College_Statements/Position_Statements/ps68pdf.aspx (accessed 21 December 2014).

RANZCP (2014) Reconciliation Action Plan 2014-2016. Royal Australian and New Zealand College of Psychiatrists. Available at https://www.ranzcp.org/Files/About_Us/RANZCP-RAP-Final.aspx (accessed 21 December 2014).

RCPsych (1983) Report of Special (Political Abuse of Psychiatry) Committee on South Africa. Bulletin of the Royal College of Psychiatrists, 7, 115

Robertson, M. \& Walter, G. (2011) Psychiatric ethics and the 'new professionalism'. In Psychiatry's Contract with Society: Concepts, Controversies and Consequences (eds D. Bhugra, A. Malik \& G. Ikkos), pp. 221-239. Oxford University Press.

Rubenstein, L. \& London, L. (2001) The UDHR and the limits of medical ethics: the case of South Africa. Health and Human Rights, 3, 160-175

Stein, D. J., Seedat, S., Kaminer, D., et al (2008) The impact of the Truth and Reconciliation Commission on psychological distress and forgiveness in South Africa. Social Psychiatry and Psychiatric Epidemiology, 43, 462-468.

Sunday Times (2014) One in three South Africans suffer from mental illness - most won't get any help. Sunday Times, 7 July. Available at http://www.timeslive.co.za/local/2014/07/07/one-inthree-south-africans-suffer-from-mental-illness---most-won-t-getany-help (accessed 21 December 2014).

TRC (1998) Truth and Reconciliation Commission of South Africa Report. Truth and Reconciliation Commission. Available at http:// www.justice.gov.za/trc/report (accessed 21 December 2014).

Ugandan Government (2009) The Anti-Homosexuality Bill, No. 18 Uganda Gazette, No. 47, vol. CII, 25 September.

United Nations (2014) Global Report on Trafficking in Persons 2014. UN

Villa-Vicencio, C. \& Du Toit, F. (eds) (2006) Truth and Reconciliation in South Africa: 10 Years On. New Africa Books.

WHO (1977) Report of the UN Special Committee Against Apartheid: Apartheid and Mental Health Care (MNH/77.5). World Health Organization.

WHO (1981) Apartheid and Health. WHO. 